\title{
Inhibition of SARS Coronavirus Infection In Vitro with Clinically Approved Antiviral Drugs
}

\author{
Emily L.C. Tan, ${ }^{*}$ Eng Eong Ooi, $†$ Chin-Yo Lin, ${ }^{*}$ Hwee Cheng Tan, $\dagger$ Ai Ee Ling, $\ddagger$ \\ Bing Lim,* and Lawrence W. Stanton*
}

Severe acute respiratory syndrome (SARS) is an infectious disease caused by a newly identified human coronavirus (SARS-CoV). Currently, no effective drug exists to treat SARS-CoV infection. In this study, we investigated whether a panel of commercially available antiviral drugs exhibit in vitro anti-SARS-CoV activity. A drugscreening assay that scores for virus-induced cytopathic effects on cultured cells was used. Tested were 19 clinically approved compounds from several major antiviral pharmacologic classes: nucleoside analogs, interferons, protease inhibitors, reverse transcriptase inhibitors, and neuraminidase inhibitors. Complete inhibition of cytopathic effects of SARS-CoV in culture was observed for interferon subtypes, $\beta-1 b, \alpha-n 1, \alpha-n 3$, and human leukocyte interferon $\mathrm{a}$. These findings support clinical testing of approved interferons for the treatment of SARS.

Cevere acute respiratory syndrome (SARS) $(1,2)$ is an $\checkmark$ infectious disease caused by a newly identified human coronavirus (SARS-CoV) $(3,4)$. The disease can produce severe pneumonia with a reported fatal outcome of $15 \%$ to 20\%. Currently, no effective drug exists to treat SARSCoV infection (5). The urgency of the outbreak has led to the empiric use of broad- spectrum antibiotics and antiviral agents in affected patients in several countries (6-12). Intensive efforts are under way to gain more insight into the mechanisms of viral replication, in order to develop targeted antiviral therapies and vaccines. Developing effective and safe vaccines and chemotherapeutic agents against SARS CoV, however, may take years.

The recent epidemic has shown that knowledge is lacking regarding the clinical management and treatment of infected patients. Ribavirin (6-12), oseltamivir (8-10), foscarnet (8), intravenous immunoglobulin (8), and other agents have been used to treat patients. Preliminary results

*Genome Institute of Singapore, Singapore; †National Environmental Agency, Singapore; and $¥$ Singapore General Hospital, Singapore from in vitro testing indicate that ribavirin concentrations that inhibit other viruses sensitive to ribavirin do not inhibit replication or cell-to-cell spread of the SARS-CoV (5). However, the U.S. Centers for Disease Control and Prevention concluded that further in vitro testing of antiviral drugs on other coronavirus isolates and more information on the clinical outcome of patients treated with ribavirin or other antiviral drugs in controlled trials is needed (5).

The aim of this study was to investigate whether a panel of currently available antiviral agents exhibit in vitro anti-SARS-CoV activity. Three general antiviral strategies are generally found (13): 1) direct antiviral effects, 2) inhibition of viral entry and replication at the cellular level by targeting virus-related processes, and 3) enhancement of host immune response. A total of 19 drugs approved for clinical use in the treatment of viral infections were tested in this study. They are representative compounds from major antiviral pharmacologic classes that are currently commercially available: nucleoside analogs, interferons, protease inhibitors, reverse transcriptase inhibitors and neuraminidase inhibitors.

A cell-based assay utilizing cytopathic endpoints (CPE) was set up using Vero E6 cells to screen these antiviral compounds. SARS-CoV has been shown to infect Vero E6 cells, an African green monkey kidney cell line (3), and this remains the only in vitro model of SARS-CoV infection. The initial screen was followed by a plaque reduction assay to determine the $50 \%$ effective concentration $\left(\mathrm{EC}_{50}\right)$ of compounds showing positive results. These experiments allow rapid screening of commercially available antiviral agents, enabling those with in vitro evidence of activity to move expeditiously into clinical studies, since safety and pharmacokinetic information in humans is already available for other disease indications.

Here we report that certain interferon subtypes exhibit in vitro inhibitory activity against SARS-CoV and are candidates for follow-up studies in animal models and patients to determine their efficacy in vivo. 


\section{Materials and Methods}

\section{Selection and Preparation of Drugs}

To rapidly identify a pharmacologic agent that could be used to treat SARS, a collection of antiviral drugs was tested against SARS-CoV, the etiologic agent of the atypical pneumonia. To investigate a wide spectrum of potential molecular targets, we decided to cover the entire pharmacologic range of commercially available antiviral agents, including agents not expected to be active against coronaviruses. Information on antiviral drugs provided here was obtained from prescribing information sheets or from communications with the manufacturer.

Nucleoside analogues are a diverse class of compounds; in general, they inhibit viral RNA or DNA polymerases or other enzymes, interfering with nucleic acid synthesis. In this study, the selected compounds that target DNA viruses such as herpes simplex virus (HSV) and varicella-zoster viruses (VZV) were acyclovir, ganciclovir, and foscarnet. Ribavirin has activity against a range of DNA and RNA viruses; in different cell lines, $\mathrm{ED}_{50}$ ranges from 1 to $100 \mu \mathrm{g} / \mathrm{mL}$. Antiretroviral (HIV) drugs include reverse transcriptase (RT) inhibitors and protease inhibitors. Selected HIV nucleoside RT inhibitors studied were zidovudine and lamivudine, while HIV protease inhibitors studied were indinavir, nelfinavir, and saquinavir. The third group of antivirals studied were the neuraminidase inhibitors, both commercially available preparations, zanamivir and oseltamivir were used in this study. Interferons were the next major class of antivirals studied. Various subtypes of interferon $\alpha$ (2a, 2b, n1, and $\mathrm{n} 3$, human leukocyte) and $\beta$ (1a and $1 \mathrm{~b}$ ) were used. Amantadine, an old antiviral compound, was also studied. Different terms have been used to express antiviral activity, namely, $\mathrm{EC}_{50}, 95 \%$ effective concentration $\left(\mathrm{EC}_{95}\right)$, and $50 \%$ inhibitory concentration ( $\mathrm{IC}_{50}$ ); Table 1 illustrates the range of activity against selected viruses.

Tenfold dilutions of the drug were tested to cover a broad range of concentrations above and below inhibitory dosages as reported by the manufacturer for other viralhost combinations. Compounds already present in aqueous injections were made up to volume by using Hank's buffered saline solution. For tablet and capsule formulations with soluble active ingredients, the outer coat was removed wherever applicable, and the preparation was ground in a mortar and pestle. The contents were dissolved in water, vortexed, and centrifuged thereafter at $3,000 \mathrm{~g}$. The required volume was pipetted from the supernatant and diluted accordingly. When the active ingredients were insoluble in water (nelfinavir and saquinavir), the contents were dissolved in dimethylsulphoxide (DMSO); care was taken to ensure that the final concentration of DMSO in the dilutions would not exceed $1 \%$. For plaque assays, fivefold
Table 1. Examples of inhibitory concentrations of antiviral drugs against selected viruses ${ }^{a}$

\begin{tabular}{|c|c|c|}
\hline Compound & $\mathrm{IC}_{50}$ & Virus \\
\hline \multirow[t]{2}{*}{ Foscavir } & $50-800 \mu \mathrm{mol} / \mathrm{L}$ & Cytomegalovirus \\
\hline & 5-443 $\mu \mathrm{mol} / \mathrm{L}$ & Herpes simplex mutants \\
\hline Acyclovir & $0.01-13.5 \mu \mathrm{g} / \mathrm{mL}$ & $\begin{array}{l}\text { Herpes smplex virus and } \\
\text { varicella-zoster virus }\end{array}$ \\
\hline Cymevene & $0.02-3.48 \mu \mathrm{g} / \mathrm{mL}$ & $\begin{array}{l}\text { Laboratory strains or clinical } \\
\text { isolates of cytomegalovirus }\end{array}$ \\
\hline \multirow[t]{3}{*}{ Ribavirin } & $1-25 \mu \mathrm{g} / \mathrm{mL}$ & Influenza \\
\hline & $25-100 \mu \mathrm{g} / \mathrm{mL}$ & HIV and other retroviruses \\
\hline & 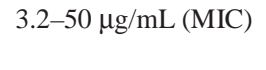 & $\begin{array}{l}\text { Herpes and poxviruses } \\
\text { suppression }\end{array}$ \\
\hline Lamivudine & $0.0006-0.034 \mu \mathrm{g} / \mathrm{mL}$ & HIV \\
\hline Zidovudine & $0.003-0.013 \mu \mathrm{g} / \mathrm{mL}$ & HIV \\
\hline Fortovase & $1-30 \mathrm{nmol} / \mathrm{L}$ & HIV \\
\hline Viracept & 7-196 nM (EC (25) $)$ & HIV \\
\hline Crixivan & $25-100 \mathrm{nmol} / \mathrm{L}$ & HIV \\
\hline Relenza & $0.005-16 \mu \mathrm{mol}$ & Influenza virus \\
\hline Tamiflu & $0.0008 \mu \mathrm{M}->35 \mu \mathrm{mol}$ & Influenza virus \\
\hline Amantadine & $0.1-25\left(\mathrm{ED}_{50}\right)$ & Influenza virus \\
\hline
\end{tabular}

drug dilutions were prepared by using growth media as specified below.

\section{SARS-CoV Production and Infection}

Vero E6 cells (American Type Culture Collection, Manassas, VA) were propagated in $75 \mathrm{~cm}^{2}$ cell culture flasks in growth medium consisting of medium 199 (Sigma, St Louis, MO) supplemented with $10 \%$ fetal calf serum (FCS; Biological Industries, Kibbutz Beit Haemek, Israel). SARS-CoV 2003VA2774 (an isolate from a SARS patient in Singapore), which has been previously sequenced (14), was propagated in Vero E6 cells. Briefly, $2 \mathrm{~mL}$ of stock virus was added to a confluent monolayer of Vero E6 cells and incubated at $37^{\circ} \mathrm{C}$ in $5 \% \mathrm{CO}_{2}$ for $1 \mathrm{~h} ; 13$ $\mathrm{mL}$ of medium 199 supplemented with 5\% FCS was then added. The cultures were incubated at $37^{\circ} \mathrm{C}$ in $5 \% \mathrm{CO}_{2}$, and the supernatant was harvested after $48 \mathrm{~h}$; in $\geq 75 \%$ of cultures, inhibition of CPE (3+) in each well was observed with an inverted microscope. The supernatant was clarified at 2,500 rpm and then divided into aliquots, placed in cryovials, and stored at $-80^{\circ} \mathrm{C}$ until use.

\section{Virus Handling and Titration}

All virus culture and assays were carried out in the biosafety level-3 laboratory at the Environmental Health Institute, according to the conditions set out in Biosafety in Microbiological and Biomedical Laboratories (15). Virus titer in the frozen culture supernatant was determined by using a plaque assay. Briefly, $100 \mu \mathrm{L}$ of virus in 10-fold serial dilution was added, in duplicates, to a monolayer of Vero E6 cells in a 24-well plate. After $1 \mathrm{~h}$ of incubation at 
$37^{\circ} \mathrm{C}$ in $5 \% \mathrm{CO}_{2}$, the viral inoculum was aspirated, and 1 $\mathrm{mL}$ of carboxymethylcellulose overlay with medium 199, supplemented with 5\% FCS, was added to each well. After 4 days of incubation, the cells were fixed with $10 \%$ formalin and stained with $2 \%$ crystal violet. The plaques were counted visually, and the virus titer in plaque-forming units per $\mathrm{mL}(\mathrm{PFU} / \mathrm{mL})$ was calculated.

\section{Cytopathic Endpoint Assay}

The protocol used was adapted from Al-Jabri et al. (16), and all drugs were tested in quadruplicate. Briefly, $100 \mu \mathrm{L}$ of serial 10 -fold dilutions of the drugs were incubated with $100 \mu \mathrm{L}$ of Vero E6 cells, giving a final cell count of 20,000 cells per well in a 96-well plate. The incubation period was $1 \mathrm{~h}$ at $37^{\circ} \mathrm{C}$ in $5 \% \mathrm{CO}_{2}$, except for the interferons, which were incubated overnight with the cells. Ten microlites of virus at a concentration of 10,000 PFU/well was then added to each of the test wells. The plates were incubated at $37^{\circ} \mathrm{C}$ in $5 \% \mathrm{CO}_{2}$ for 3 days and observed daily for $\mathrm{CPE}$. The end point was the drug dilution that inhibited $100 \%$ of the CPE $\left(\mathrm{CIA}_{100}\right)$ in quadruplicate wells. To determine cytotoxicity, $100 \mu \mathrm{L}$ of serial 10 -fold dilutions of the drugs was incubated with $100 \mu \mathrm{L}$ of Vero E6 cells, giving a final cell count of 20,000 cells per well in a 96-well plate, without viral challenge. The plates were then incubated at $37^{\circ} \mathrm{C}$ in $5 \% \mathrm{CO}_{2}$ for 3 days and examined for toxicity effects by using an inverted microscope.

\section{Plaque Reduction Assay}

Trypsinized Vero E6 cells were resuspended in growth medium and preincubated with interferons (serial fivefold dilution) in quadruplicate wells in 24-well plates. The next day, the medium was aspirated, and $100 \mu \mathrm{L}$ of virus was added to each well at a titer of $100 \mathrm{PFU} /$ well. After incubation for $1 \mathrm{~h}$, the virus inoculum was aspirated, and a carboxymethylcellulose overlay containing maintenance medium and the appropriate interferon concentration was added. After 4 days' incubation, the plates were fixed and stained as described previously. The number of plaques was then counted visually, and the concentration of drug that inhibits $50 \%$ of plaques in each well $\left(\mathrm{IC}_{50}\right)$ was deter- mined. Results were plotted in Microsoft Excel, and a polynomial of order three was used to approximate the data and extrapolate $\mathrm{IC}_{50}$ and $\mathrm{IC}_{95}$ values.

\section{Results}

\section{Cell-based Assay of SARS-CoV Infection}

High titers of infectious SARS-CoV, originally derived from a respiratory sample of a SARS patient, were propagated on Vero E6 cells. The CPE of SARS-CoV on Vero E6 was evident within 24 hours after infection (Figure 1). SARS-CoV-infected cells display a CPE characterized by the appearance of rounded cells and the destruction of the monolayer.

\section{Antiviral Drug Activity}

A collection of 19 antiviral drugs was tested in the SARS-CoV CPE inhibition assay (Table 2). The set of drugs tested included seven interferons, five nucleoside analogs, three protease inhibitors, two RT inhibitors, and two neuraminidase inhibitors. Complete inhibition of the CPE was observed for four of the seven interferons in the initial screen when very high viral challenge of $10^{4}$ $\mathrm{PFU} /$ well and a high multiplicity of infection $(\mathrm{MOI}=0.5)$ rate were used. Complete inhibition, expressed as CIA $_{100}$, was observed for interferon $\beta$ - $1 \mathrm{~b}$ (Betaferon) at 5,000 $\mathrm{IU} / \mathrm{mL}$, interferon $\alpha$-n3 (Alferon) at 5,000 IU/mL, interferon $\alpha$-n1 (Wellferon) at 250,000 IU/mL, and human leukocyte interferon $\alpha$ (Multiferon) at 500,000 IU $/ \mathrm{mL}$. Ribavirin also completely inhibited the CPE at 5,000 $\mu \mathrm{g} / \mathrm{mL}$ (Table 3). None of the other drugs showed complete inhibition of CPE, even at the highest concentration of drug tested (Table 2).

Rebif (IFN- $\beta$-1a) showed slight inhibition of CPE at $250,000 \mathrm{IU} / \mathrm{mL}$, but the inhibition was not complete at the screening virus load of 10,000 PFU/well. Likewise, Roferon (IFN- $\alpha-2 a$ ) showed slight, incomplete inhibition at 50,000 IU/mL. Because the criteria for ascertaining antiSARS-CoV activity in this screen were set at $100 \%$ inhibition of CPE, and as high doses of interferons may result in severe clinical side effects, we chose to conduct further
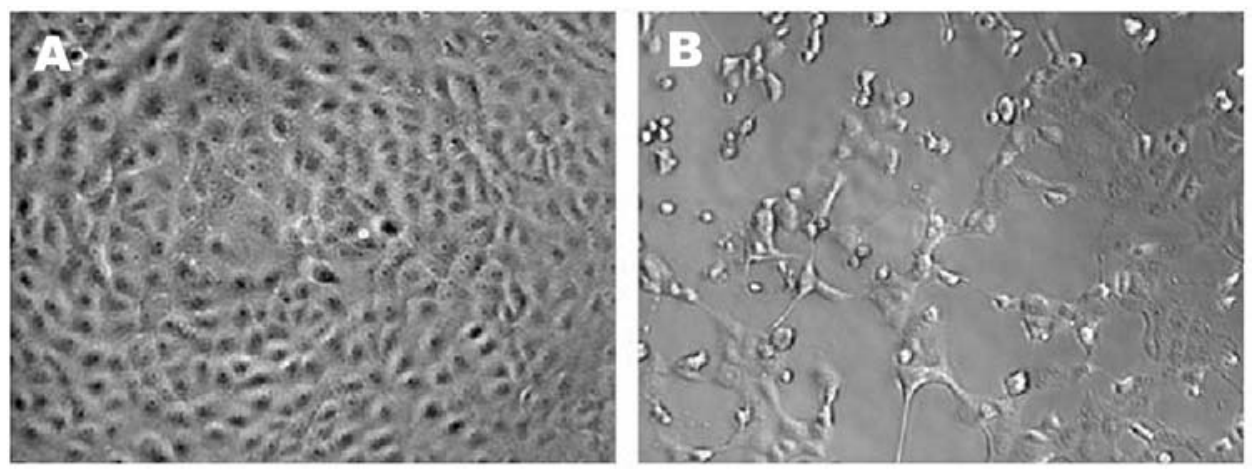

Figure 1. Microscopic appearance of control $(A)$ and infected (B) Vero E6 cells, demonstrating cytopathic effects. 
Table 2. Commercially available antiviral agents tested, source and starting concentration

\begin{tabular}{|c|c|c|c|}
\hline Antiviral agent & Source & Highest concentration tested & Inhibition of cytopathic effect $\left(\mathrm{CIA}_{100}\right)$ \\
\hline \multicolumn{4}{|l|}{ Interferons } \\
\hline Interferon $\alpha$-2a (Roferon) & Roche & $100,000 \mathrm{IU} / \mathrm{mL}$ & No \\
\hline Interferon $\alpha$-2b (Intron $\mathrm{A}$ ) & Schering-Plough & $500,000 \mathrm{IU} / \mathrm{mL}$ & No \\
\hline Interferon $\alpha$-n1 (Wellferon) & GlaxoSmithKline & $500,000 \mathrm{IU} / \mathrm{mL}$ & Yes \\
\hline Interferon $\alpha$-n3 (Alferon) & Hemispheryx & $10,000 \mathrm{IU} / \mathrm{mL}$ & Yes \\
\hline Interferon $\beta$-1a (Rebif) & Serono & $500,000 \mathrm{IU} / \mathrm{mL}$ & No \\
\hline Interferon $\beta$-1b (Betaferon) & Schering AG & $100,000 \mathrm{IU} / \mathrm{mL}$ & Yes \\
\hline \multicolumn{4}{|l|}{ Nucleoside analogs } \\
\hline Acyclovir & Faulding & $1,000 \mu \mathrm{g} / \mathrm{mL}$ & No \\
\hline Ganciclovir (Cymevene) & Roche & $50,000 \mu \mathrm{g} / \mathrm{mL}$ & No \\
\hline Ribavirin & ICN Pharma & $10,000 \mu \mathrm{g} / \mathrm{mL}$ & Yes \\
\hline \multicolumn{4}{|l|}{ Protease inhibitors } \\
\hline Indinavir (Crixivan) & Merck & $100 \mu \mathrm{mol} / \mathrm{L}$ & No \\
\hline Nelfinavir (Viracept) & Roche & $10,000 \mathrm{nmol} / \mathrm{L}$ & No \\
\hline Saquinavir (Fortovase) & Roche & $10,000 \mathrm{nmol} / \mathrm{L}$ & No \\
\hline \multicolumn{4}{|c|}{ Reverse transcriptase inhibitors } \\
\hline Lamivudine (Epivir) & GlaxoSmithKline & $1,000 \mu \mathrm{mol} / \mathrm{L}$ & No \\
\hline Zidovudine (Retrovir) & GlaxoSmithKline & $1,000 \mu \mathrm{g} / \mathrm{mL}$ & No \\
\hline \multicolumn{4}{|l|}{ Neuraminidase inhibitors } \\
\hline Oseltamivir (Tamiflu) & Roche & $10,000 \mu \mathrm{mol} / \mathrm{L}$ & No \\
\hline Zanamivir (Relenza) & GlaxoSmithKline & $1,000 \mu \mathrm{mol} / \mathrm{L}$ & No \\
\hline \multicolumn{4}{|l|}{ Other } \\
\hline Amantadine (Symmetrel) & Novartis & $1,000 \mu \mathrm{g} / \mathrm{mL}$ & No \\
\hline Foscarnet (Foscavir) & AstraZeneca & $8,000 \mu \mathrm{mol} / \mathrm{L}$ & No \\
\hline
\end{tabular}

evaluations only in the interferons that showed complete inhibition from initial screen, namely, Wellferon, Multiferon, Betaferon, and Alferon.

Based upon results of the primary screen, the four active interferons and ribavirin were retested at two lower viral challenges, $10^{3}$ and $10^{2} \mathrm{PFU} /$ well. All four drugs again showed inhibitory effect, although the $\mathrm{CIA}_{100}$ were dependent on viral loads (Table 3 ). At the lowest viral load the CIA $_{100}$ were $5 \mathrm{IU} / \mathrm{mL}$ for both interferon $\beta$-1b (Betaferon) and human leukocyte interferon $\alpha$ (Multiferon); and 50 and $250 \mathrm{IU} / \mathrm{mL}$ for interferon $\alpha$-n3 (Alferon) and interferon $\alpha-n 1$ (Wellferon), respectively. No cytotoxicity of the interferons was observed at or near inhibitory concentrations. Ribavirin showed inhibitory activity at all three viral loads, but only at high concentrations of the drug, $0.5-5 \mathrm{mg} / \mathrm{mL}$. At high concentrations of ribavirin $(0.2-1 \mathrm{mg} / \mathrm{mL})$ cytotoxic effects were observed on VeroE6 cells, as has been reported for other cell types $(17,18)$. As such, we consider ribavirin to be inactive against SARS-CoV.

A plaque reduction assay format with $100 \mathrm{PFU}$ of SARS-CoV $(\mathrm{MOI}=0.0005)$ was conducted to determine the $\mathrm{IC}_{50}$ for Betaferon, Alferon, and Multiferon, the three compounds that showed greatest potency for inhibition of CPE. Additional supply was not available for testing interferon $\alpha$-n1 (Wellferon), as production of this drug has been discontinued. Cells were preincubated for $15 \mathrm{~h}$ with fivefold dilutions of drug. Viral-induced plaques, which developed in 3 days, were counted to determine the inhibitory effect of the drugs at various concentrations. All three interferon preparations displayed a dose-dependent inhibition of SARS-CoV plaque formation in this assay (Figure 2). The $\mathrm{IC}_{50}$ and $\mathrm{IC}_{95}$ were determined to be 0.2 and $8 \mathrm{IU} / \mathrm{mL}$ for Betaferon, 0.8 and $200 \mathrm{IU} / \mathrm{mL}$ for Alferon, and 2 and $44 \mathrm{IU} / \mathrm{mL}$ for Multiferon.

\section{Discussion}

Betaferon, Alferon, Multiferon, Wellferon, and ribavirin inhibited CPE in SARS-CoV-infected Vero E6 cells, in decreasing order of potency. Ribavirin, a drug widely used in initial efforts to manage SARS infections, inhibited CPE completely at $500-5,000 \mu \mathrm{g} / \mathrm{mL}$ at virus loads of $100-10,000$ PFU per well. The concentration range observed is much higher than concentrations that inhibit other viruses (respiratory syncytial virus, $\mathrm{ED}_{50} 2-8$ $\mu \mathrm{g} / \mathrm{mL}$, HIV or resistant strains of rhinovirus, $50-100$ $\mu \mathrm{g} / \mathrm{mL}$ ), including viruses that were tested on Vero cells (West Nile virus, New York isolate $178 \mu \mathrm{g} / \mathrm{mL}$, and Uganda isolate $41 \mu \mathrm{g} / \mathrm{mL}$ ) (19). In addition, the CPE

\begin{tabular}{lcccc}
\hline \multicolumn{5}{l}{$\begin{array}{l}\text { Table 3. Complete inhibition of cytopathic effect }\left(\mathrm{ClA}_{100}\right) \\
\text { different virus titers }\end{array}$} \\
\hline $\begin{array}{l}\text { Virus load } \\
(\mathrm{PFU} / \text { well })\end{array}$ & $\begin{array}{c}\text { Ribavirin } \\
(\mu \mathrm{g} / \mathrm{mL})\end{array}$ & $\begin{array}{c}\text { Wellferon } \\
(\mathrm{IU} / \mathrm{mL})\end{array}$ & $\begin{array}{c}\text { Betaferon } \\
(\mathrm{IU} / \mathrm{mL})\end{array}$ & $\begin{array}{c}\text { Alferon } \\
(\mathrm{IU} / \mathrm{mL})\end{array}$ \\
\hline 10,000 & 10,000 & 500,000 & 10,000 & 10,000 \\
1,000 & 10,000 & 5,000 & 1,000 & 1,000 \\
100 & 1,000 & 500 & 10 & 100 \\
\hline
\end{tabular}



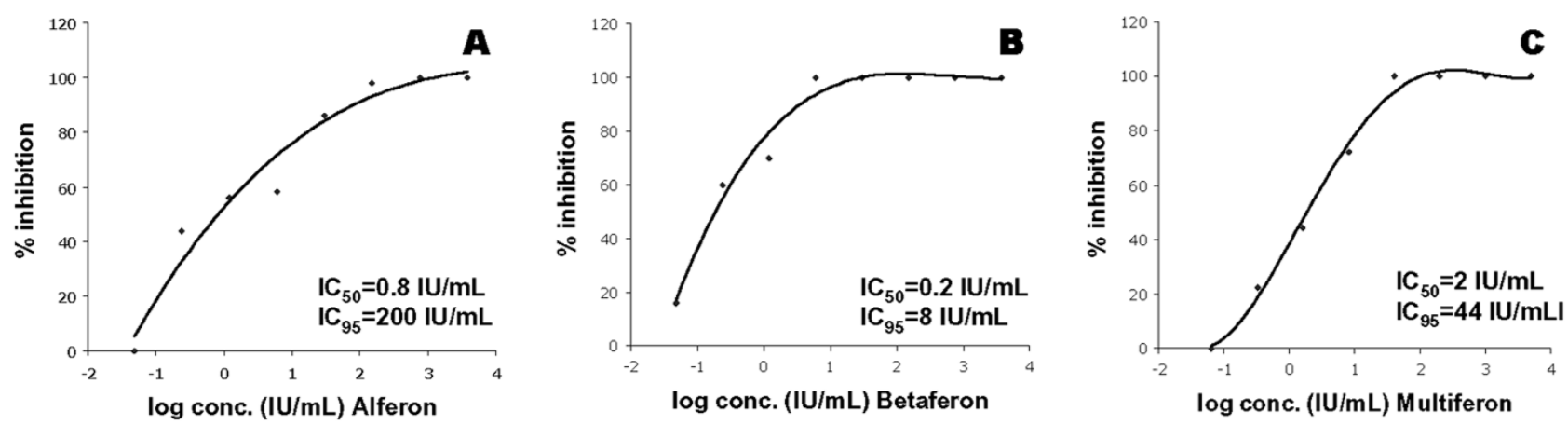

Figure 2. Dose-response curves for Alferon (A), Betaferon (B), and Multiferon $(C)$ as determined by plaque reduction assays. $I C_{50}(50 \%$ inhibitory concentration) and $\mathrm{IC}_{95}$ (95\% inhibitory concentration) values were calculated by using the fitted functions describing the curves.

inhibitory concentrations obtained in this study were above the cytotoxic concentration range against Vero cells. The $50 \%$ cytotoxic dose $\left(\mathrm{CD}_{50}\right)$ on various cell lines has been reported to be approximately $200-1000 \mu \mathrm{g} / \mathrm{mL}$ of ribavirin $(17,18)$. We observed slight cytotoxicity by microscopic examination of the cells, making it difficult to accurately obtain in vitro efficacy data against SARS-CoV. It appears that due to the low activity of ribavirin in vitro, inhibitory doses may not be achievable clinically. It is possible that ribavirin would be more effective in combination with interferons. Combination therapy with ribavirin and interferon $\alpha$ has now become standard treatment for chronic hepatitis C (20-22). Additionally, we have tested the effect of ribavirin and Betaferon in combination (range of concentration of ribavirin, 1-100 $\mu \mathrm{g} / \mathrm{mL}$; range of concentration of Betaferon, 0.1-10 IU/mL). At 1,000 PFU, this combination did not demonstrate observable synergistic inhibitory effect against SARS-CoV.

This study describes in vitro activity of four interferon subtypes against the SARS-CoV. Interferons have been used as anticancer and antiviral agents, in particular, for treating hepatitis B and C infections. Various groups have reported the clinical benefit of intranasally administered interferon $\alpha$ in human volunteers before and after inoculation with non-SARS coronaviruses (23-25). The antiviral activity of interferons is mediated by direct effects on infected cells or by modulating an immune response (26). Interferons interact with specific surface cell receptors, leading to production of interferon-stimulated gene products such as $2^{\prime} 5^{\prime}$-oligoadenylate synthase and protein kinase PKR (27).

In SARS-CoV infection, a convenient starting point for the use of interferons against a SARS-CoV infection would be the usual clinical doses for the treatment of hepatitis B or C. Common clinical dosages for interferon $\alpha$ range from 3 to 5 million IU three times a week to 5 million IU daily. For interferon $\beta$, data regarding efficacy in the treatment of hepatitis $\mathrm{C}$ are conflicting, and interferon $\beta$ (at doses of 3 to 6 million IU three times weekly) is usually only used in the treatment of infections in patients whose condition no longer responds to other therapies. Plasma levels of interferons administered through the subcutaneous route are usually low with correspondingly short half-lives. In view of their mechanism of action, absolute serum levels may not be meaningful as a measure of the biologic activity of interferons, compared to the induction of cellular products such as $2^{\prime} 5^{\prime}$ oligoadenylate synthase.

Interferon activity varies among different cell types $(28,29)$, however. Specific interferon subtypes which inhibit SARS-CoV in Vero cells may not necessarily have the same effect in other cells; the converse may also be true- that those drugs that are negative in Vero cells may be effective in other cell types. We are currently identifying other in vitro models of SARS-CoV infection that will enable us to address cell-type specific drug effects. Also, interferon subtypes exhibited different activity against SARS-CoV in this study. The mechanism for the difference in activity is unknown. Among the products tested, the source of interferon and amount of glycosylation differ. Some preparations were derived from human lymphoblastoid or leukocyte cells, while others were recombinantly produced in Escherichia coli or mammalian cell culture. We do not know the importance of this observation with respect to possible antiviral mechanisms of the interferons against SARS-CoV or potential clinical implications of these differences.

This study describes rapid screening of commercially available compounds for extension into in vivo research. Evidence of activity and data from in vitro studies, however, cannot be easily correlated with clinical performance but rather present promising candidates for follow-up studies. Definite recommendations on anti-SARS-CoV activity of compounds in humans can only be made in the in vivo setting. In conclusion, interferon $\beta-1 b, \alpha-n 1, \alpha-n 3$, and human leukocyte interferon $\alpha$ exhibit antiviral activity in an in 
vitro model and are potential drugs for in vivo research and clinical management of SARS-CoV infection.

\section{Acknowledgments}

We thank Edison Liu for his critical review of the manuscript, and the pharmaceutical companies that provided compounds for the assay experiment: Roche, Novartis, GlaxoSmithKline, Merck Sharpe and Dohme, Serono, Schering AG, Schering-Plough, Viragen, Hemispheryx, and AstraZeneca.

Ms. Tan is a pharmacist with a special interest in pharmacology and clinical research. She was scientific manager at the Singapore Cancer Syndicate, Genome Institute of Singapore, and is now clinical research manger at Pfizer Ltd. in Singapore.

\section{References}

1. World Health Organization. Acute respiratory syndrome in Chinaupdate 3: disease outbreak reported: Geneva: The Organization; 2003.

2. Lee N, Hui DH, Wu A, Chan P, Cameron P, Joynt GM, et al. A major outbreak of severe acute respiratory syndrome in Hong Kong. N Engl J Med 2003;348:1986-94.

3. Ksiazek TG, Erdman D, Goldsmith C, Zaki SR, Peret T, Emery S, et al. A novel coronavirus associated with severe acute respiratory syndrome. N Engl J Med 2003;348:1953-66.

4. Tsang KW, Ho PL, Ooi GC, Yee WK, Wang T, Chan-Yeung M, et al. A cluster of cases of severe acute respiratory syndrome in Hong Kong. N Engl J Med 2003;348:1977-85.

5. Severe acute respiratory syndrome (SARS) and coronavirus testingUnited States, 2003. MMWR Morb Mortal Wkly Rep 2003;52:297-302.

6. Peiris JSM, Chu CM, Cheng VC, Chan KS, Hung IF, Poon LL, et al. Clinical progression and viral load in a community outbreak of coronavirus-associated SARS pneumonia: a prospective study. Lancet 2003;361:1767-72.

7. Chan-Yeung M, Yu WC. Outbreak of severe acute respiratory syndrome in Hong Kong Special Administrative Region: case report. BMJ 2003;326:850-2.

8. Nicholls JM, Poon LL, Lee KC, Ng WF, Lai ST, Leung CY, et al. Lung pathology of fatal severe acute respiratory syndrome. Lancet 2003;361:1773-8.

9. Poutanen SM, Low DE, Henry B, Finkelstein S, Rose D, Green K, et al. Identification of severe acute respiratory syndrome in Canada. N Engl J Med 2003;348:1995-2005.

10. Drosten C, Gunther S, Preiser W, van der Werf S, Brodt HR, Becker $\mathrm{S}$, et al. Identification of a novel coronavirus in patients with severe acute respiratory syndrome. N Engl J Med 2003;348:1967-76.

11. Lapinsky SE, Hawryluck L. ICU management of severe acute respiratory syndrome. Intensive Care Med 2003;29:870-5.

12. Booth CM, Matukas LM, Tomlinson GA, Rachlis AR, Rose DB, Dwosh HA, et al. Clinical features and short-term outcomes of 144 patients with SARS in the greater Toronto area. JAMA 2003;289:2801-9. Erratum in: JAMA 2003;290:334.

13. Driscoll JS. Antiviral drugs. Aldershot, UK: Ashgate Publishing Ltd; 2002.

14. Ruan YJ, Wei CL, Ee AL, Vega VB, Thoreau H, Su ST, et al. Comparative full length genome sequence analysis of 14 SARS coronavirus isolates and common mutations associated with putative origins of infection. Lancet 2003;361:1779-85. Erratum in: Lancet 2003;361:1832.
15. Richmond JY, McKinney RW. Biosafety in microbiological and biomedical laboratories. 4th ed. Washington: U.S. Government Printing Office; 1999.

16. Al-Jabri AA, Wigg MD, Oxford JS. Initial in vitro screening of drug candidates for their potential antiviral activities. In: Mahy, BWJ, Kangro HO, editors. Virology methods manual. London: Academic Press Ltd; 1996. p. 293-356.

17. Huffman JH, Sidwell RW. Khare GP, Witkowski JT, Allen LM, Robins RK. In vitro effect of 1-beta-D-ribofuranosyl-1,2,4-triazole-3carboxamide (Virazole, ICN-1229) on deoxy-ribonucleic acid and ribonucleic acid viruses. Antimicrob Agents Chemother 1973;3:235-41.

18. Saganuma T, Ishida N. An evaluation of a new antiviral agent 'Virazole' against influenza virus infections. Tohoku J Exp Med 1973;110:405-6.

19. Morrey JD, Smee DF, Sidwell RW, Tseng C. Identification of active antiviral compounds against a New York isolate of West Nile virus. Antiviral Res 2002;55:107-16.

20. Davis GL, Esteban-Mur R, Rustgi V, Hoefs J, Gordon SC, Trepo C, et al. Interferon alpha2b alone or in combination with ribavirin for the treatment of relapse of chronic hepatitis. $N$ Engl J Med 1998;339:1493-9.

21. Poynard TP, Marcellin P, Lee SS, Niederau C, Minuk GS, Ideo G, et al. Randomised trial for interferon alpha2b plus ribavirin. Lancet 1998;352:1426-32.

22. McHutchison JG, Gordon SC, Schiff ER, Shiffman ML, Lee WM, Rustgi VK, et al. Interferon alpha2b alone or in combination with ribavirin as initial treatment for hepatitis C. N Engl J Med 1998; 339:1485-92.

23. Turner RB, Felton A, Kosak K, Kelsey DK, Meschievitz CK. Prevention of experimental coronavirus colds with intranasal alpha2b interferon. J Infect Dis 1986;154:443-7.

24. Higgins PG, Phillpotts RJ, Scott GM, Wallace J, Bernhardt LL, Tyrrell DA. Intranasal interferon as protection against experimental respiratory coronavirus infection in volunteers. Antimicrob Agents Chemother 1983;24:713-5.

25. Tyrrell DA. The efficacy and tolerance of intranasal interferons: studies at the common cold unit. J Antimicrob Chemother 1986;18B:153-6.

26. Pfeffer LM, Dinarello CA, Herberman RB, Williams BR, Borden EC, Bordens R, et al. Biological properties of recombinant alpha-interferons: 40th anniversary of the discovery of interferons. Cancer Res 1998;58:2489-99.

27. Lee CK, Bluyssen HA, Levy DE. Regulation of interferon alpha responsiveness by the duration of Janus kinase activity. J Biol Chem 1997;272:21872-7.

28. Weingartl HM, Derbyshire JB. Antiviral activity against transmissible gastroenteritis virus, and cytotoxicity, of natural porcine interferons alpha and beta. Can J Vet Res 1991; 55:143-9.

29. Jordan LT, Derbyshire JB. Antiviral activity of interferon against transmissible gastroenteritis virus in cell culture and ligated intestinal segments in neonatal pigs. Vet Microbiol 1994;38:263-76.

Address for correspondence: Lawrence W. Stanton, Genome Institute of Singapore, 60 Biopolis Street, Singapore 138672; fax: +65-6478-9051; email: stanton@gis.a-star.edu.sg

The opinions expressed by authors contributing to this journal do not necessarily reflect the opinions of the Centers for Disease Control and Prevention or the institutions with which the authors are affiliated. 